
and Aromatic Plants

An International Journal

ISSN: 2619-9645 | e-ISSN: 2667-5722

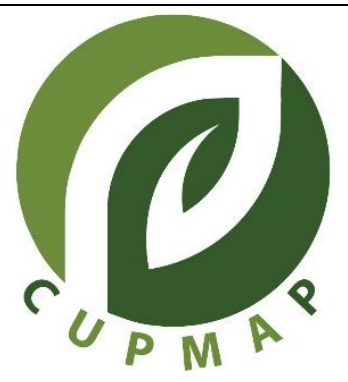

\title{
Effect of a Tropical Plant (Hunteria umbellata) in the Management of Streptozotocin Induced Diabetes Mellitus and other Physiological and Biochemical Functions in Wistar Rats
}

\author{
$\underline{\text { Fidelis Ifeakachukwu OKOLAFOR }}^{1^{*}}{ }^{\text {iD }}$, Frederick Osaro EKHAISE2 ${ }^{2}$ iD \\ ${ }^{1}$ Department of Science Laboratory Technology, Faculty of Life Sciences, University of Benin \\ ${ }^{2}$ Department of Microbiology, Faculty of Life Sciences, University of Benin, Nigeria \\ Te: +2347034191830 \\ *Corresponding author: fidelis.okolafor@uniben.edu
}

\begin{abstract}
Hunteria umbellata seeds, leaves and root are used as decoctions in Western and Southern part of Nigeria for the treatment of blood related ailments. The antidiabetic effect of Hunteria umbellata extracts (aqueous and methanol) on hematological, lipid profile and biochemical parameters in streptozotocin-induced diabetes in female Wistar rats was studied. The qualitative phytochemical screening of the seed extracts was determined using standard chemical methods. Twenty five Wistar rats weighing between $117 \mathrm{~g}$ and $170 \mathrm{~g}$ were shared into five groups of five animals per group for the physiological studies. All treatment groups were administered $500 \mathrm{mg} / \mathrm{kg}$ per body weight of $\mathrm{H}$. umbellata extracts. Group I; normal control, Group II; negative or diabetic control, Group III; metformin + streptozotocin (STZ), Group IV; aqueous extract of $H$. umbellata + STZ and Group V; methanol extract of H. umbellata + STZ. Diabetes was induced with $55 \mathrm{mg} / \mathrm{kg}$ body weight STZ. Qualitative phytochemical screening of aqueous and methanol seed extracts of $H$. umbellata revealed the presence of secondary metabolites such as saponins, phytate, oxalate, anthraquinones, cyanogenic glycoside, phenols and alkaloids were recorded highest concentrations in both extracts. The hypoglycaemic studies of methanol extract revealed significant $(\mathrm{p}<0.005)$ reduction on the fasting blood glucose levels of experimental animals for Group V compared to moderate reduction in Group III. Group IV recorded increase in the blood glucose levels of Wistar rats. The haematological parameters were not significant $(p>0.05)$ for all treatment groups. Group V recorded significance $(p<0.05)$ amount of high density lipoproteins (HDL), total cholesterol (CHOL), triglyceride (TRIG) and low density lipoproteins (LDL) while CHOL was significant $(\mathrm{p}<0.05)$ for Group III. The biochemical parameters were within safe limit. The methanol extract of $\mathrm{H}$. umbellata possesses the potentials for the managements of blood glucose levels and other physiological and biochemical functions compared to conventional drug (Metformin).
\end{abstract}

Key Words: Antidiabetic, Phytochemical screening, Streptozotocin, Wistar rats, Hunteria umbellata

(c) CUPMAP. All rights reserved.

\section{Introduction}

Diabetes mellitus (DM) is a chronic and endocrine disorder caused by inherited and/or acquired deficiency in the production of insulin by the pancreas
(Selvaraju et al., 2013). The prevalence of DM is increasing across the world. In 2011, it was estimated that over 346 million people lived with DM worldwide (WHO, 2011). Nearly $80 \%$ of deaths due to DM occur in low and middle income countries 
particularly in sub-Saharan Africa. Medicinal plants are known to possess bioactive components that may be used in the treatment and management of illness and disease condition in traditional medicine practice as a result of high cost of orthodox drugs and low potency of some orthodox drugs. Hunteria umbellata K. Schum, is a tree with a height of about $15-22 \mathrm{~m}$ belonging to the family Apocynaceae. The leaves of $H$. umbellata are broad, abruptly acuminate and broadly lineate (Gurib-Fakim, 2006). The plant is grown mostly in Southern parts of Nigeria, Ghana and the rainforest regions of Cameroon (Aderele et al., 2020). Many dialects in Nigeria have different names for the plant such as Osu (Edo), Erinor abeere (Yoruba, Southwest) and Nkpokiri (Igbo, Southeast). H. umbellata have been reported to be used for traditional medicine for the treatment of various ailments (Reynolds and Sofowora, 1984; Keay et al., 1989). The trees of $H$. umbellata are used as ornamental plants in Southern part of Nigeria where it is planted for shades and decoration and guarded jealously by owners from human scavengers. Localities in Western and Southern part of Nigeria apply the leaves, seeds and root of $H$. umbellata with other plants mixed with coconut water as decoctions for the treatment of fever, blood pressure, piles, headache and other body related ailments. The stem of the plant are used as chewing stick, due to the cleansing effect derived from its use as an alternative to tooth brush. Many researchers have reported the medicinal uses of $H$. umbellata such as treatment of ulcers, diabetes mellitus and dysmenorrhoea (Oboh et al., 2017).

This study examines the antidiabetic effect of aqueous and methanol seed extracts of $\mathrm{H}$. umbellata and its effect on hematological, lipid profile and biochemical parameters in streptozotocin-induced diabetes in female Wistar rats.

\section{Material and Methods}

\subsection{Sample Collection and Identification}

The seeds of Hunteria umbellata were purchased from Oshodi Markets in Oshodin Local Government Area, Lagos State in April 2015. The seeds were air dried for three weeks, after which the epicarps were removed and further air dried for another three weeks to obtain constant weight. The air drying was carried out to protect the bioactive components of the plant seed. The identification of the plant was carried out by Dr. E. I. Aigbokhan, of the Plant Biology and Biotechnology, Faculty of Life Sciences, University of Benin, Benin City.

\subsection{Preparation of Sample}

The dried plant seeds of $H$. umbellata were pulverized using electronic grinder Lab. Mill (Model: Serial NO. 4745, Christy and Norris Ltd, England). The pulverized seeds were stored in air tight plastic container for experimental analyses.

\subsection{Extraction of Plant Materials}

$400 \mathrm{~g}$ of the seeds were blended using a sterile grinder. The blended seeds were transferred into Pyrex flask containing 1.5 litres of aqueous (sterile distilled water) and non-aqueous solvent (methanol) and allowed to soak for $24 \mathrm{~h}$ for the aqueous and $72 \mathrm{~h}$ for the non-aqueous mixture. After 24 $\mathrm{hr}$ the mixture was macerated using a sterile cotton wool. At the end of extraction, the homogenate was filtered through a Whatman Filter Paper No. 1 using a glass funnel. The filtrates were labeled accordingly for subsequent use. The filtrates were concentrated using Water Bath at temperature of $80^{\circ} \mathrm{C}$ to dryness. The crude extract was obtained and stored for further analyses. 


\subsection{Percentage Yield}

The percentage yield of $H$. umbellata was obtained using the methods of Kao (2018). The percentage yield was computed using the mathematical formula below:

Yield $\%=\frac{W_{2}-W_{1}}{W_{0}}$

$\mathrm{W}_{2}=$ Weight of extract + container $\mathrm{W}_{1}=$ Weight of container

$\mathrm{W}_{1}=$ Weight of container

$\mathrm{W}_{0}=$ Initial weight of sample before extraction

\subsection{Qualitative Phytochemical components of Hunteria umbellata}

The qualitative phytochemical analyses of the selected plant seeds were determined using the methods of Price (1985) and Thirumalai et al. (2011). All determinations were carried out in triplicates.

\subsection{In-vivo Diabetic Study}

Twenty five female Wistar rats weighing between $117 \mathrm{~g}$ and $170 \mathrm{~g}$ were shared into five groups of five animals per group. The animals were allowed to acclimatize for three weeks before administration of drugs. Freshly prepared solution of streptozotocin (STZ) (Sigma, USA), $55 \mathrm{mg} / \mathrm{kg}$ body weight in $0.1 \mathrm{~mol} / \mathrm{L}$ of cold citrate buffer $\mathrm{pH} 4.1$ was introduced into the overnight fasted animals by a single intra-peritoneal injection (Igbe et al., 2009). The control experimental animals were injected with distilled water. The animals were considered diabetic at the blood glucose level values above $250 \mathrm{mg} / \mathrm{dL}$ on the third day after STZ injection using a glucometer and acute test strip. The diabetic animals were treated for three weeks, while blood glucose levels were taken on a weekly basis.

\subsection{Experimental Animal Grouping}

Twenty five experimental animals of five animals per group were shared for experimentation as follows:
Group I- Normal control (non-diabetic rats)

Group II- Negative control (diabetic without treatment)

Group III- Positive control (diabetic +500 $\mathrm{mg} / \mathrm{kg}$ body weight Metformin)

Group IV- Diabetic + $500 \mathrm{mg} / \mathrm{kg}$ body weight of aqueous seed extract of $H$. umbellata.

Group V- Diabetic $+500 \mathrm{mg} / \mathrm{kg}$ body weight of methanol seed extract of $H$. umbellata.

\subsection{Extract Administration and Observation}

Three days after induction of diabetes, experimental animal Groups III, IV, and V were treated with $500 \mathrm{mg} / \mathrm{kg}$ body weight standard drug (Metformin), $500 \mathrm{mg} / \mathrm{kg}$ body weight aqueous seed extract of $H$. umbellata and $500 \mathrm{mg} / \mathrm{kg}$ body weight methanol crude extract of $H$. umbellata respectively.

Group I (control) was administered distilled water at each treatment and Group II (negative control) was left untreated. Treatments (Aqueous and methanol seed extract of $H$. umbellata) were administered orally to the respective groups at a dose of $500 \mathrm{mg} / \mathrm{kg}$.

\subsection{Collection of Blood Samples and Plasma Preparation for Analysis}

The experimental animals were sacrificed by anesthetizing the rats in enclosed container with chloroform. Blood samples were collected by ocular punctures into the abdominal aorta and the heart (Adeneye and Adeyemi, 2009). The blood was further centrifuged for $10 \mathrm{~min}$ at $3000 \mathrm{rpm}$ using the centrifuge. The clear supernatants (plasma) collected were used for the 
estimation of lipid profiles and liver function tests.

\subsection{Determination of Animal Body Weight}

The initial weights of all the experimental animals in the different experimental groups were determined at the start of the experiment. Weekly weight measurements of the experimental animals were taken in all the groups and values recorded. The final weight measurement was carried out on the last day of the experiment. The differences in the weight in the various groups recorded accordingly (Bain et al., 2017).

\subsection{Determination of Blood Glucose Level}

The initial blood glucose of fasting Wistar rats before STZ induction was taken using a glucometer with acute test strip. The weekly blood glucose was taken in all groups of animals by pricking the tail of the rats and blood dropped on a strip fastened to the glucometer; this was carried out weekly for the three weeks study (Bain et al., 2017).

\subsection{Haematological Study of Blood Samples of Experimental Animals}

The serum obtained from the blood of the experimental animals were analysed for haematological parameter at the Department of Haematology, University of Benin Teaching Hospital (UBTH), Benin City, Nigeria. Blood samples was analysed for packed cell volume (PCV), haemoglobin level (Hb), total white blood cells count (TWBC) and differential white blood cells counts (DWBC) according to the methods of Trinder (1969).

\subsection{Determination of Plasma Lipid Profiles}

The plasma total protein (TP), total cholesterol (TG), triglyceride (TG) and HDLcholesterol (HDL-Chol) were determined according to the methods of Friedewald et al. (1972) using Randox Diagnostic kit. Low density lipoprotein-cholesterol (LDLChol) was calculated using formula adopted by Xing-Jiu et al. (2006).

\subsection{Biochemical Analysis (Liver function test)}

The liver function test was carried by digesting the plasma in Teco diagnostic (TC) kits and measured using the spectrophotometer. Plasma obtained from clotted blood samples from experimental animals were analyzed for alkaline phosphatase (ALP). Aspartate transaminase (AST) and alanine transaminase (ALT) was determined following the methods of Reitman et al. (1957) and Azwanida (2015).

\subsection{Statistical Analyses}

Data obtained were analyzed by one-way analysis of variance (ANOVA) using Student T-test to determine the significance differences in group results.

\section{Results and Discussion}

Medicinal plants have repeatedly been used as non-prescription medication for type 2 diabetes in rural areas in sub-Saharan Africa. Their potency may be due to several factors that are yet to be completely studied. H. umbellata is one medicinal plant that has been explored for its antidiabetic properties. The percentage yield of aqueous and methanol seed extracts of $H$. umbellata revealed highest solubility in aqueous (48.73\%) solvent compared to methanol (3.765\%) (Table 1).

Table 1. Percentage yield profile of aqueous and methanol crude extracts of $H$. umbellate

\begin{tabular}{|c|c|c|c|c|}
\hline Solvent & W2 (g) & W1 (g) & W0 (g) & Yield \% \\
\hline Aqueous & 493.41 & 298.5 & 400 & 48.73 \\
\hline Methanol & 156.06 & 141.0 & 400 & 3.765 \\
\hline
\end{tabular}


The result showed that the seed of $H$. umbellata was more soluble in polar solvent compared to non-polar solvent. The high percentage yield, with preserved integrities of the extracts is an indication that the method of extraction can be adopted as a standard method of extract preparation, using the common available equipment in our laboratories as alternatives to other standard equipment that are not readily available (Niranjan and Kanaki, 2008). Qualitative phytochemical screening of aqueous and methanol seed extracts of $H$. umbellata indicated the presence of secondary metabolites such as alkaloids, phenols, saponins, phytate, oxalate, anthraquinones (Table 2). It was reported that medicinal plants with hypoglycemic and antidiabetic effect usually contain high concentration of alkaloids and flavonoids (Murray et al., 1994). The result of Qualitative phytochemicals of $H$. umbellata in this study does not completely agree with this assertion. Alkaloids and phenol was highest compared to other secondary metabolites for aqueous and methanol extracts.

Table 2. Qualitative phytochemical screening of aqueous and methanol crude extracts of $H$. umbellata.

\begin{tabular}{lcc}
\hline \multirow{2}{*}{ Parameters } & \multicolumn{2}{c}{$\mathbf{~ m g / k g}$} \\
& Aqueous & Methanol \\
\hline Oxalate & 9.9 & 3.7 \\
Phytate & 6.6 & 2.3 \\
Tannins & 0.2 & 0.3 \\
Flavonoids & 0.0 & 0.3 \\
Saponins & 12.8 & 6.4 \\
Alkaloids & 20.8 & 19.0 \\
Phenols & 8.1 & 26.7 \\
Cyanogenicglycoside & 3.6 & 3.9 \\
Anthraquinones & 8.4 & 7.7 \\
\hline
\end{tabular}

Experimental animals induced with STZ have been reported to produce a diabetic state that is characterized by loss of weight, polydipsia, polyuria, glucosuria, polyphagia, hypoinsulinaemia and hyperglycemia (Subash-Babu et al., 2007). The effect of $H$. umbellata extracts on the fasting body weight of experimental animals revealed weight changes in Group I, II and Group IV (Table 3). Group I recorded significant $(p<0.002, p<0.001)$ increase in body weight compared to other treatment groups that received $55 \mathrm{mg} / \mathrm{kg}$ body weight STZ. Group II recorded significant $(\mathrm{p}<0.05)$ decrease for week 1 and 2. Group IV showed significant $(p<0.05)$ decrease in weight for week 1 and week 2 . Group III and V had no significant $(p>0.05)$ difference in the body weight of experimental animals for 21 days treatment period. The decrease in body weight for Groups II and IV may be attributed to the underutilization of glucose due to the hyperglycemic action in both groups. This result is in agreement with the work of Muhd et al. (2012), who reported that the decrease in the body weight of diabetic rats may be due to catabolism of fats and protein.

Diabetes mellitus is a metabolic endocrine disorder which affects multiple organs, causing severe complications such as the destruction of 68 to $80 \%$ beta cell of the islet of Langerhans (Adeneye et al., 2013). These destruction results in the increase in the blood glucose level (hyperglycemia). The fasting blood glucose level after STZ induction compared to fasting blood sugar level after three weeks treatments revealed normal blood glucose level for group 1 and hyperglycemia in Group II. Group III treated with standard drug (Metformin) recorded significant $(p<0.05)$ decrease at week one and week three, while Group V (treated with methanol seed extracts of $H$. umbellata) recorded significant $(\mathrm{p}<0.05)$ decrease in blood sugar levels for week one and two and high significant $(\mathrm{p}<0.005)$ decrease for week three (Figure 1). 
Table 3. Effects of $H$. umbellata seed extracts on the fasting body weight (FBW) of experimental animals

\begin{tabular}{lcccc}
\hline Group & $\begin{array}{c}\text { FBW before } \\
\text { STZ (g) }\end{array}$ & $\begin{array}{c}\text { FBW after } \\
\text { Week } \mathbf{1}(\mathbf{g})\end{array}$ & $\begin{array}{l}\text { FBW after } \\
\text { Week } \mathbf{~ ( g )}\end{array}$ & $\begin{array}{l}\text { FBW after } \\
\text { Week } \mathbf{~ ( g )}\end{array}$ \\
\hline I & $147.7 \pm 6.86$ & $164.7 \pm 8.09^{* * *}$ & $168.3 \pm 8.19^{* *}$ & $175.4 \pm 8.03^{* * *}$ \\
II & $134.0 \pm 6.15$ & $123.6 \pm 4.38^{*}$ & $121.6 \pm 3.94^{*}$ & $122.8 \pm 2.96$ \\
III & $139.5 \pm 5.62$ & $133.3 \pm 6.64$ & $135.3 \pm 6.73$ & $138.4 \pm 10.8$ \\
IV & $160.4 \pm 5.81$ & $136.7 \pm 6.03^{*}$ & $133.3 \pm 5.81^{*}$ & $128.6 \pm 12.4$ \\
V & $164.2 \pm 4.31$ & $177.0 \pm 9.65$ & $178.8 \pm 8.96$ & $182.9 \pm 7.65$
\end{tabular}

Body weight in Mean \pm SEM, $n=5$, Significance at $\mathrm{p}<0.05$, " $\mathrm{p}<0.002$, " $\mathrm{p}<0.001$ compared to FBW before STZ induction, FBW: fasting body weight Group I: Normal control (no diabetes)

Group II: Negative control (induced $55 \mathrm{mg} / \mathrm{kg}$ BW STZ)

Group III: Positive control ( $55 \mathrm{mg} / \mathrm{kg}$ BW STZ $+500 \mathrm{mg} / \mathrm{kg}$ BW Metformin) Group IV:

$55 \mathrm{mg} / \mathrm{kg}$ BW STZ + $500 \mathrm{mg} / \mathrm{kg}$ BW Aqueous extract of $H$. umbellata Group V: $55 \mathrm{mg} / \mathrm{kg}$ BW

$\mathrm{STZ}+500 \mathrm{mg} / \mathrm{kg}$ BW Methanol extract of $H$. umbellata

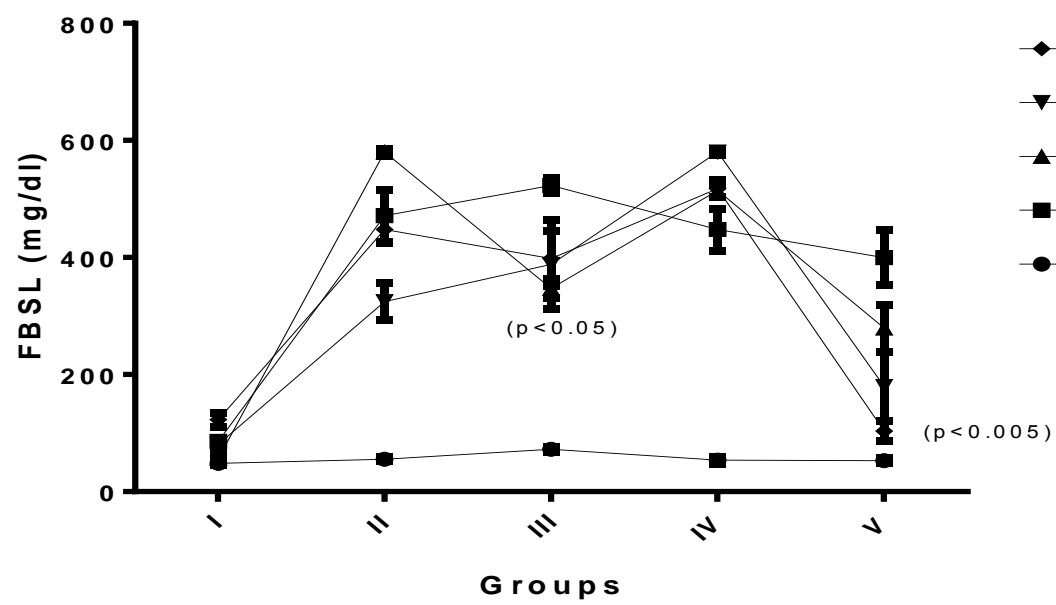

FBSL in Mean \pm SEM, $\mathrm{n}=5$, Significance at ${ }^{*} \mathrm{p}<0.05,{ }^{* *} \mathrm{p}<0.005$ compared to FBSL after STZ induction, FBSL: fasting blood sugar level
Group I: Normal control (no diabetes)
Group II: Negative control (induced 55mg/kg BW STZ)
Group III: Positive control $(55 \mathrm{mg} / \mathrm{kg}$ BW STZ $+500 \mathrm{mg} / \mathrm{kg}$ BW Metformin)
Group IV: $55 \mathrm{mg} / \mathrm{kg}$ BW STZ $+500 \mathrm{mg} / \mathrm{kg}$ BW Aqueous extract of $H$. umbellata
Group V: $55 \mathrm{mg} / \mathrm{kg}$ BW STZ $+500 \mathrm{mg} / \mathrm{kg}$ BW Methanol extract of $H$. umbellata

Figure 1. Effect of $H$. umbellata seed extracts on the fasting blood sugar level (FBSL) of experimental animals

Group IV recorded increase blood sugar levels for the three weeks treatment period, indicating that the aqueous extract of the plants does not possess antidiabetic properties. The levels of blood glucose for Group IV treated with methanol seed extracts of $H$. umbellata were more statistically significant compared to Group III treated with standard drug due to the reduction in blood glucose levels. The result of this study confirmed that methanol extract of $H$. umbellata may best be used in the management of diabetic condition as a result of its reducing tendencies of blood sugar level of diabetic experimental animals compared to the Metformin. The result of this study correlates with several authors' findings (Adeneye and Adeyemi. 2009a; Adeneye and Adeyemi, 2009b; Adeneye and Crooks, 2015, Kakade et al., 1972) who reported significant reduction of blood glucose levels of streptozotocin-induced diabetes mellitus in experimental animals treated with methanol extract of $H$. umbellata. 
The examination of blood serum is a good way of assessing the health status as it plays a vital role in physiological, nutritional and pathological status of individuals (Ayinde et al., 2010; Ashafa et al., 2009). Hematological parameters are used to determine the extent of deleterious effect on blood constituents of animals (Rees, 2007; Adesokan and Akanji, 2010). It is used to explain blood related functions of chemical compounds/plant extract (Onoja et al., 2018). The mean hematological parameters for all groups showed no significance $(p>0.05)$ (Table 4$)$.

Three weeks observation may not be enough to allow for hemolysis of blood. Therefore, longer weeks of monitoring may be encouraged to ascertain the actual effect of the plant extract on hematological parameters. This result contradicts the report on the significant reduction of hematological parameters of alloxaninduced diabetics (Ogbera et al., 2009; Dave et al., 2019). Diabetes mellitus (DM) has been reported to be associated with cardiovascular morbidity and this may partly be explained by the abnormal lipid profile which is sometimes a feature of DM (Han et al., 2012). The study of the effect of $H$. umbellata on the lipid profile of streptozotocin-induced experimental animals showed lipid profile parameters such as HDL, CHOL and LDL in all experimental groups (Table 5). Group V recorded significance $(\mathrm{p}<0.05)$ amount of HDL, CHOL, TRIG and LDL while CHOL was significant $(p<0.05)$ for Group III. Other lipid profile parameters in this study showed no statistical significance ( $p>0.05$ ). The high cholesterol level may be attributed to the presence of hypertension for diabetic conditions which however may be contributory factor in the prevalence of dyslipidemia in type $2 \mathrm{DM}$. This result agrees with the reports of Harris (2005) and Kyoungho et al. (2014), who reported that high cholesterol presence in plasma of diabetic experimental animals treated with plant extract confirms the rise in blood pressure for animals that are diabetic.

Table 4. Effects of $H$. umbellata seed extracts on the hematological parameters of experimental animals

\begin{tabular}{|c|c|c|c|c|c|c|}
\hline Parameters & $\begin{array}{c}\text { Unit of } \\
\text { measurement }\end{array}$ & Group I & Group II & Group III & Group IV & Group V \\
\hline WBC & $\left(\times 10^{3} / \mathrm{ul}\right)$ & $12.83 \pm 4.64$ & $6.240 \pm 0.44$ & $7.140 \pm 1.01$ & $17.63 \pm 8.01$ & $8.600 \pm 0.45$ \\
\hline LY & $\%$ & $50.50 \pm 10.6$ & $45.26 \pm 9.25$ & $51.32 \pm 3.91$ & $48.80 \pm 14.1$ & $49.00 \pm 2.35$ \\
\hline MO & $\%$ & $6.533 \pm 0.81$ & $9.700 \pm 1.62$ & $9.540 \pm 1.07$ & $7.533 \pm 0.49$ & $7.367 \pm 0.58$ \\
\hline GR & $\%$ & $42.97 \pm 10.8$ & $45.02 \pm 8.06$ & $39.14 \pm 3.11$ & $43.67 \pm 15.4$ & $43.63 \pm 1.78$ \\
\hline $\mathrm{RBC}$ & $\left(\times 10^{6} / \mathrm{ul}\right)$ & $5.873 \pm 0.44$ & $6.398 \pm 0.164$ & $6.504 \pm 0.33$ & $4.933 \pm 0.71$ & $5.803 \pm 0.27$ \\
\hline $\mathrm{Hgb}$ & $\mathrm{g} / \mathrm{dl}$ & $12.97 \pm 0.94$ & $13.40 \pm 0.47$ & $15.20 \pm 0.36$ & $11.00 \pm 1.19$ & $13.00 \pm 0.65$ \\
\hline PCV & $\%$ & $38.67 \pm 1.37$ & $40.70 \pm 1.18$ & $41.46 \pm 1.97$ & $34.97 \pm 2.64$ & $38.43 \pm 1.87$ \\
\hline PLT & $(\times 103 /$ ul $)$ & $797.3 \pm 63.2$ & $300.8 \pm 106$ & $422.8 \pm 148$ & $539.0 \pm 27.5$ & $752.7 \pm 55.1$ \\
\hline
\end{tabular}


Table 5. Effect of $H$. umbellata on the Lipid profile of streptozotocin-induced diabetic experimental animals

\begin{tabular}{ccccc}
\hline \multicolumn{5}{c}{ mg/dL } \\
\hline Group & HDL & CHOL & TRIG & LDL \\
\hline I & $138.68 \pm 15.01$ & $155.89 \pm 14.69$ & $66.667 \pm 12.13$ & $36.720 \pm 16.35$ \\
II & $158.83 \pm 9.058$ & $140.75 \pm 9.948$ & $92.436 \pm 18.87$ & $38.854 \pm 14.84$ \\
III & $140.75 \pm 21.74$ & $* 199.50 \pm 18.66 \mathrm{a}^{*}$ & $107.56 \pm 28.07$ & $39.150 \pm 17.89$ \\
IV & $124.24 \pm 24.32$ & $184.46 \pm 4.780$ & $91.877 \pm 37.61$ & $49.250 \pm 19.39$ \\
V & $103.39 \pm 17.00 \mathrm{a}^{*}$ & $194.49 \pm 12.29^{*}$ & $46.497 \pm 32.51 \mathrm{a}^{*}$ & $81.803 \pm 19.19 \mathrm{a}^{*}$ \\
\hline
\end{tabular}

Lipid profile in Mean \pm SEM, $n=5$, Significance at ${ }^{a^{*}} p<0.05$ with respect to normal control, ${ }^{*}<0.05$ with respect to negative control, HDL: High density lipoproteins, CHOL: Total cholesterol, TRIG: Triglyceride, LDL: Low density lipoproteins Group I: Normal control (no diabetes), Group II: Negative control (induced 55mg/kg BW STZ)

Group III: Positive control (55mg/kg BW STZ + 500mg/kg BW Metformin) Group IV: 55mg/kg BW STZ + 500mg/kg BW Aqueous extract of H. umbellata Group V: $55 \mathrm{mg} / \mathrm{kg}$ BW

$\mathrm{STZ}+500 \mathrm{mg} / \mathrm{kg}$ BW Methanol extract of H. umbellata

The liver plays a major role in the regulation of carbohydrate homeostasis as a result of the hepatocellular glycogen accumulation which leads to hepatomegaly and liver enzyme abnormalities in poorly controlled diabetes patients (Han et al., 2012). Liver function tests (LFTs) are used in clinical practice to screen potential damage to liver, monitor the progression of known disease, and monitor the effects of potentially hepatotoxic drugs (Harris, 2005). Type 2 DM have been reported to be associated with higher incidence of abnormal LFT compared to the individuals without diabetes, elevated ALT being the most common abnormality (Harris, 2005). The study on the effect of $H$. umbellata on the liver function test of streptozotocin-induced diabetic animals revealed the mean liver enzymes in this study such as ALT, AST, ALP for all experimental groups (Table 6). ALT showed significance $(\mathrm{p}<0.05)$ decrease for Group V while AST and ALP were not statistically significant for Group I to group IV. The result of ALT, ALP and ALP for Group I to Group V were within safe limits (Kyoungho et al., 2014; Harris, 2005).

Table 6. Effect of $H$. umbellata on the liver function test of Streptozotocin-induced diabetic experimental animals

\begin{tabular}{cccc}
\hline \multicolumn{4}{c}{ U/L } \\
\hline Group & ALT & AST & ALP \\
\hline I & $20.617 \pm 2.70$ & $24.633 \pm 3.87$ & $80.820 \pm 12.3$ \\
II & $22.137 \pm 0.95$ & $29.460 \pm 5.22$ & $119.59 \pm 29.9$ \\
III & $29.419 \pm 3.46$ & $25.800 \pm 2.56$ & $74.794 \pm 15.2$ \\
IV & $25.264 \pm 3.39$ & $19.980 \pm 2.05$ & $64.610 \pm 2.97$ \\
V & $13.373 \pm 4.25^{*}$ & $28.333 \pm 2.11$ & $42.467 \pm 6.09$ \\
\hline
\end{tabular}

Liver enzymes in Mean \pm SEM, $n=5$, Significance at ${ }^{*} \mathrm{p}<0.05$ with respect to normal control, ${ }^{*} \mathrm{p}<0.05$ with respect to negative control, ALT: Alanine transaminase, AST: Aspartate Aminotransferase, ALP: Alkaline phosphatase,

Group I: Normal control (no diabetes), Group II: Negative control (induced 55mg/kg BW STZ), Group III: Positive control (55mg/kg BW STZ + 500mg/kg BW Metformin) Group IV: $55 \mathrm{mg} / \mathrm{kg}$ BW STZ $+500 \mathrm{mg} / \mathrm{kg}$ BW Aqueous extract of H. umbellata Group V: $55 \mathrm{mg} / \mathrm{kg}$ BW STZ $+500 \mathrm{mg} / \mathrm{kg}$ BW Methanol extract of H. Umbellate 


\section{Conclusion}

Failure of over the counter drugs in the management of patients with high blood sugar level (diabetes) has continued to draw attention to research into medicine plants as alternative to orthodox drugs. Medicinal plants possess phytochemical compounds depending of the extracting solvent used. The result of this study showed positive antidiabetic properties, significant physiological and biochemical functions on Wistar rats administered with methanol seed extract of $H$. umbellate. The methanol extract of $H$. umbellata possesses the potentials for the managements of blood glucose levels in experimental animals compared to Metformin. Attention should be drawn to proper utilization of medicinal plants in the management of diabetes condition in sub Saharan Africa.

\section{Acknowledgements}

The Authors wish to acknowledge the following persons for their contribution to this work: Dr. D. O. Uwaya (Department of Science Laboratory Technology, Uniben) for his contribution to the animal study and Mr. S. Odidika (Splendid Research Laboratory, Benin City) for his contribution to the phytochemical studies and Dr. S. O. Uanseoje (Department of Biochemistry, Uniben) for his contribution to the Biochemical assay.

\section{Author Contribution}

Fidelis Ifeakachukwu OKOLAFOR carried out the research and wrote the manuacript

Frederick Osaro EKHAISE suppervised the project, did the editing of manuscript

\section{Conflicts of Interest}

There were no conflicts of interest in the course of this research.

\section{References}

1. Adeneye, A.A. and Crooks, P.A., 2015. Weight losing, antihyperlipidemic and cardioprotective effects of the alkaloid fraction of Hunteria umbellata seed extract on normal and triton-induced hyperlipidemic rats. Asian Pacific Journal of Tropical Biomedicine, 5(5):387-394. http://dx.doi.org/10.1016/s22211691(15)30374-9

2. Adeneye, A.A., Crooks, P. A., Fadhel-Albayati, Z., Miller, A., Zito, S.W., Adeyemi, O.O. and Agbaje, E.O., 2013. The novel antihyperglycaemic action of Hunteria Umbellata seed fractions mediated via intestinal glucose uptake inhibition. African Journal of Traditional, Complementarily and Alternative Medicine,10(2):189-202. http://dx.doi.org/10.4314/ajtcam.v10i2.3

3. Adeneye, A.A. and Adeyemi, 0.0., 2009a. Hypoglycaemic effects of the aqueous seed extract of Hunteria umbellata in normoglycaemic and glucose and nicotine-induced hyperglycaemic rats. International Journal of Natural Product Resources, 2(1):9-18. http://doi:10.1055/s-00281084243

4. Adeneye, A.A. and Adeyemi, 0.0., 2009b. Further evaluation of antihyperglycaemic activity of Hunteria umbellata K. Schum Hallier F. seed extract in experimental diabetes. Journal of Ethnopharmacology, 126(2): 238-243. htpps://doi: 10.1016/j.jep.2009.08.037

5. Adeneye, A.A., Crooks, P. A., Fadhel-Albayati, Z., Miller, A., Zito, S.W., Adeyemi, E.O. Agbaje, 2013. The novel antihyperglycaemic action of Hunteria Umbellata seed fractions Mediated via intestinal glucose uptake inhibition. African Journal of Traditional, Complement and Alternative Medicine, 10(2):189-202. https://doi.org/10.1055/s0030-1265859

6. Aderele, O.R. Rasaq, A.K. and Momoh, J.O., 2020. Phytochemical screening, mathematical analysis and antimicrobial activity of methanolic seed extract of Hunteria Umbellata. European Journal of Medicinal Plants, 1-17. http://dx.doi.org/10.9734/ejmp/2020/v31i1630 325

7. Adesokan, A. and Akanji, M. 2010. Haematological changes following chronic administration of aqueous extract of Enantia chlorantha to albino rats. Tropical Journal of Health and Science, 17(1). http:// dx.doi.org/10.4314/tjhc.v17i1.52791

8. Ashafa, O.T., Yakubu, M.T., Grierson, D.S. and Afolayan, A.J., 2009. Toxicological evaluation of the aqueous extract of Felicia muricata Thunb. leaves in Wistar rats. African Journal of Biotechnology, 8: 949-54 
https://doi.org/10.3109/13880200903373664

9. Ayinde, O.E., Ojo, V., Adeyina, A.A. and Adesoye, O., 2010. Economics of using Cocoa bean shell as feed supplement for rabbits. Pakistan Journal of Nutrition, 9:195-197. https://doi: 10.3923/pgn.2010.195.197

10. Azwanida, N.N., 2015. A Review on the extraction methods use in medicinal plants, principle, strength and limitation. Medicinal and Aromatic Plants, 4: 196. https://doi:10.4172/21670412.1000196

11. Bain, B.J., Bates, I. and Laffan, M.A., 2017. Dacie and Lewis Practical Haematology (12th edition), Elsevier,London,652p. https://doi.org/10.1111/bjh.14872

12. Dave, M., Gupta, A.K. and Heernath, P.P., 2019. Correlation between fasting blood sugar level, HbA1C level and serum lipid levels in Type 2 diabetes mellitus patients. International Journal of Contemporarily Medical Research, 6(7). http://dx.doi.org/10.21276/ijcmr.2019.6.7.13

13. Friedewald, W.T., Levy, R.I. and Fredrickson, D.S., 1972. Estimation of the concentration of lowdensity lipoprotein cholesterol in plasma, without use of the preparative ultracentrifuge. Clinical Chemistry,18:499-502.

https://doi.org/10.1093/clinchem/18.6.499

14. Gurib-Fakim, A., 2006. Medicinal plants: Traditions of yesterday and drugs of tomorrow. Molecular Aspects of Medicine, 27(1): 1-9. https://doi.org/10.1016/j.mam.2005.07.008

15. Han, N., Htoo, H.K.S. and Aung, H., 2012. Determinants of abnormal liver function tests in diabetes patients in Myanmar. International Journal of Diabetes Research, 1(3):36-41. http://dx.doi.org/10.5923/j.diabetes.20120103.0 2

16. Harris, E.H., 2005. Elevated liver function tests in type 2 diabetes. Clinical Diabetes, 23(3):115- 119. http://dx.doi.org/10.2337/diaclin.23.3.115

17. Igbe, I., Omogbai, E.K.I. and Ozolua, R.I., 2009. Hypoglycaemic activity of aqueous seed extract of Hunteria umbellata in normal and streptozotocininduced diabetic rats. Pharmaceutical Biology, 47(10):1011-1016. https://doi.org/10.1080/13880200902973803

18. Kakade, M.L., Simons, N.R., Liener, I.E. and Lambert, J.W., 1972. Biochemical and nutritional assessment of different varieties of soybeans. Journal of Agricultural and Food Chemistry, 20:8790. htpps://doi: 10.1021/jf60179a024
19. Kao, F.J., 2018. Effect of extracting solvents on antioxidant activities from fruit of Phyllanthus emblica Linn. Medicinal and Aromatic Plants, 07. http://dx.doi.org/10.4172/2167-0412-c1- 018

20. Keay, R.W.J., Onochie, C.F.A. and Stanfield, D.P., 1989. Tree of Nigeria (formerly Nigerian trees, 1960, 1964), Oxford University, Oxford, UK 234pp.

21. Kyoungho, L., Joohee, H. and Soo-Geun, K., 2014. Increasing risk of diabetes mellitus according to liver function alterations in electronic workers. Journal of Diabetes Investigation, 5:671-676. http://dx.doi.org/10.1111/jdi.12202.

22. Muhd, H.M.I, Siti, B.B., Mohamad, O. and Jamaludin, M., 2012. Protective role of Hibiscus sabdariffa calyx extract against streptozotocin induced sperm damage in diabetic rats. Experimental and Clinical Psychopharmacology, 11:659-669. https:// doi:10.17877/DE290R-5145

23. Murray, P., Pitt, B. and Webb, R.C., 1994. Ramipril prevents hypersensitivity to phenylephrine in aorta from streptozotocin-induced diabetic rats. Diabetologia, 37(7): 664-670. http://dx.doi.org/10.1007/s001250050161

24. Niranjan, R.M. and Kanaki, S., 2008. Phytochemical standardization of herbal drugs and polyherbal formulations. Bioactive Molecules and Medicinal Plants, UK, pp. 349-369. https://doi:10.1007/9783-540-74603-4_19

25. Oboh, G., Adebayo, A.A. and Ademosun, A.O., 2017. Erection-stimulating, anti-diabetic and antioxidant properties of Hunteria umbellata and Cylicodiscus gabunensis water extractable phytochemicals. Journal of Complementary and Integrated Medicine, 15(1). http://dx.doi.org/10.1515/jcim2016-0164

26. Ogbera, A.O., Fasanmade, O.A., Chinenye, S. and Akinlade. A., 2009. Characterization of lipidparameters in diabetes mellitus - a Nigerian report. International Archives of Medicine, 2(19):1-7. http://dx.doi.org/10.1186/1755-76822-19

27. Onoja, S.O., Udem, S.C. and Anaga, A.O. 2018. Ameliorative effects of Helianthus annuus against nephrotoxic, cardiac, and haematological disorders in alloxan-induced hyperglycae mia in albino rats. Journal of Veterinary Research, 62(3): 371-377. http://dx.doi.org/10.2478/jvetres2018-005

28. Price, R., 1985. Phytochemical methods - a guide to modern techniques of plant analysis. Physiological Plant Pathology, 27(2):255-256. 
http://dx.doi.org/10.1016/0048-4059(85)90073-

6

29. Rees, A.J., 2007. A comparison of the haematological effects of pregnancy on the Han Wistar ra. Toxicology, 240(3): 165-166. http://dx.doi.org/10.1016/j.tox.2007.06.044

30. Reitman, S. and Frankel, S., 1957. A colorimetric method for the determination of serum glutamic oxalacetic and glutamic pyruvic transaminases. American Journal of Clinical Pathology, 28(1):5663. http://doi: 10.1093/ajcp/28.1.56

31. Reynolds, T. and Sofowora, A., 1984. Medicinal plants and traditional medicine in Africa. Kew Bulletin,39(3):667.

http://dx.doi.org/10.2307/4108615

32. Selvaraju, K, Narayanaswamy, T. Thirunavukkarasu and T. Gangaipillai, A., 2013. Anti diabetic effect of methanolic leaf extract of Pongamia pinnata on streptozotocin induced diabetic rats. Journal of Coast Life Medicine, 1(2):113-117. https://doi:10.12980/JCLM.1.2013J9

33. Subash-Babu, P., Prabuseenivasan, S. and Ignacimuthu, S.C., 2007. A potential antidiabetic agent. Phytomedicine, 14: 15-22. https://doi: 10.1016/j.phymed.2006.11.005

34. Thirumalai,T., Theresa, V.S., Elumalai, E.K. and David, E., 2011. Hypoglycemic effect of Brassica juncea (seeds) on streptozotocin induced diabetic male albino rat. Asian Pacific Journal of Tropical Biomedicine, 4:323-325. http://doi: 10.1016/S2221-1691(11)60052-X

35. Trinder, P., 1969. Determination of blood glucose using an oxidase-peroxidase system with a noncarcinogenic chromogen. Journal of Clinical Pathology,22(2):158-161. https://dx.doi.org/10.1136/jcp.22.2.158

36. World Health Organization (WHO). World health statistics. 2011;170. ISBN ISBN: 978- 92-4256419-8

37. Xing-Jiu, H., Yang-Kyu, C., Hyung-Soon, I., Oktay, Y., Euisik, Y. and Hak-Sung, K., 2006. Aspartate aminotransferase (AST/GOT) and alanine aminotransferase (ALT/GPT) detection techniques. MDPI, 6: 756- 